\title{
ILO and the international labour standards setting: a case of Nigeria labour acts
}

\author{
Genty Kabiru Ishola \\ Department of Industrial Relations \& Public Administration, Faculty of Management Sciences, Lagos State University, Ojo-Lagos, \\ Nigeria
}

\author{
Email address: \\ gentyaries2000@yahoo.com
}

\section{To cite this article:}

Genty Kabiru Ishola. ILO and the International Labour Standards Setting: A Case of Nigeria Labour Acts. Journal of Human Resource Management. Vol. 1, No. 1, 2013, pp. 15-20. doi: 10.11648/j.jhrm.20130101.13

\begin{abstract}
This study examines how International Labour Organisation set-up a labour conventions and the role Nigeria government play in using these conventions to create National Labour Acts. The idea was critically investigated to measure the effect of such labour standards in Nigeria that adopted the convention, while the weakness on the part of Ministry of Labour, Employment and Productivity was also ascertained in order to ensure proper compliance. The study makes use of secondary information as a means of gathering data while discourse content analysis was used to develop a concluding remarks on the subject matter. It was revealed from the study that the convention enforcements are weak, if not totally nonexistence. Thus, the supervisory bodies of ILO must work tirelessly to ensure vivid implementation of ratified conventions, failure to comply by the member states should called for stiff penalty.
\end{abstract}

Keywords: Labour Standard, Nigeria, ILO, Labour Acts and Conventions

\section{Introduction}

ILO was founded in 1919 and became the first specialized agency of United Nations as an international organisation responsible for drawing up and overseeing international labour standards. According to UN Report (1946) ILO was saddled with the responsibility of bringing together representatives of the tripartite ${ }^{15}$, that is, worker representatives, employer representatives and government representatives to jointly shape policies and programmes, that will promotes decent work for all.

Somavia (2012) said ILO started with 44 member states and six international labour conventions has been adopted since inception ${ }^{14}$. Presently, member states have rose to 183 while 16 international labour conventions and 18 recommendations have been adopted in less than two years, between 2010 and 2012 .

Nigeria became a member state of ILO on $17^{\text {th }}$ October, 1960 and since then has ratified 39 conventions out of which 35 were in force and the remaining 4 were denunciated. However, of the 35 ratified conventions, the paper shall focus on convention 87 of 1948 (freedom of association and protection of the right to organise), convention 98 of 1949 (Rights to organise a Collective
Bargaining). Also, the paper will look at convention no. 155 of 1949 (amended) in 1981 (Occupational Safety and Health convention).

These conventions shall be thoroughly examined from International Labour Organisation positions in relations to National Employment Laws of Nigeria as well as explore the mechanisms for the adoption of these conventions. Finally, the implementation of these conventions will be ascertained and ILO supervisory role will be measured against the failure of the member states such as Nigeria to execute these conventions to the latter while the consequence of such action will be identified.

\section{ILO and Nigeria Employment Laws Challenges}

According to ILO report (2004:143) international labour standards has been designed since ILO inception in 1919 aimed at promoting opportunities for decent and productive work under the conditions of freedom, equity, security and dignity. The benefits of international labour standards cannot be underestimated to member states because the standards is a path to decent work agenda whereby workers 
are seen as human beings and not a commodity that needs to be treated with dignity ${ }^{9}$.

International Labour Standards (ILS) refer to the conventions agreed upon by international actors (workers, employer and government representatives) which emerged from a series of value judgements, set of principles for the protection of worker rights, enhances job security among workers and improve on their terms and conditions of employment on a global scale ${ }^{9}$ (ILO, 2004). The purpose of such standards is to established a minimum standard of protection against inhumane labour practices among the member states through the adoption and implementation of such measures.

Again, the benefits of International Labour Standards (ILS) can be observed from an international legal framework for fair and stable globalisation. Here, it focuses on making sure that economic growth and development go along with the creation of decent work whereby minimum social standards were set-up for the tripartite to follow. The ILS is to create a level playing ground where the interest of all the social partners are taken into consideration and protected.

It is also used as a means of improving economic performance as well as strategy for reducing poverty rate. The benefits of ILS is enormous to the country that implement them because the international labour standards is a consensus on how a particular labour problem could be tackled at the global level and reflect knowledge as well as experience from all corners of the world ${ }^{7}$ (ILO Reports,2003).

However, if the benefits of ILS to countries that adopt and implement the conventions are enormous, the question that comes to mind is why do Nigeria not effectively implementing these policies? Two major reasons can be adduced for this. One is the constitution of Federal Republic of Nigeria which empowered legislative arms of government to do a thorough deliberation on foreign treaties before execution, even if such policies has been ratified by the country.

This is in line with ILO position that once a standard is adopted, member states are required under the ILO constitution to submit them to their competent authority (normally the parliamentary) for consideration. Even, if the standard is ratified at a convention. The countries must be committed to apply these conventions in its national laws and practices while reporting its application at regular intervals to ILO for necessary assistance if the need be.

Another reason for the failure of international labour standards in Nigeria is the relegated attitude of the government at the centre. That is, implementation of the ratified convention has not always been effective owing to capacity challenges in ensuring compliance by centre government and lack of adequate awareness of the provision of such conventions. Thus, these two major reasons attributed for the failure to implement ratified conventions will be explore in the next section of this paper while it effect will be mentioned and solution will be recommended in order to remove Nigeria name from the blacklist of ILO.

\section{Nigeria Labour Legislations and ILS}

As mentioned earlier that the constitution of Federal Republic of Nigeria is one of the hindrances that prevent vivid implementation of the ILS. Nigeria is a dualist system $^{10}$, therefore any international treaties or laws must be domesticated by the National Assembly before it can be enforced (Mbah and Ikemefuna, 2011).

Section 12 of the Constitution of the Federal Republic of Nigeria, 1999 provides unambiguously that "no treaty between the federation and any other country shall have the force of law except to the extent to which any such treaty has been enacted into law by the National Assembly". In spite of the fact that an undomesticated but ratified ILO conventions cannot be legally enforced in Nigeria, the conventions are nevertheless useful as indicating best practice on a given labour or social issues (Mbah \& Ikemefuna, 2011).

However, Nigeria labour laws was based on the need to bring the existing labour laws in line with ratified conventions which had not been passed into law by the National Assembly ${ }^{10}$. This becomes pertinent because ILO plays an important role in providing government with the necessary information and acts as a platform on which labour policies and laws are formulated at the national levels.

Aturu (2008) stressed the need for states to be familiar with the work of the ILO by virtue of its constitution. He maintained that this will enables the member states to respect some fundamental principles of ILO and specifically deal with them, particularly in the area of promoting and practice decent work agenda ${ }^{1}$. Therefore, the adoption of ILO conventions should be accelerated by the National Assembly during sessions and ensure proper compliance among the tripartite in order for labour standards to play a very vital role in regulating contract of employment and other issues of labour relations, most especially where Nigeria laws does not cover.

Another challenges that hindered full implementation of some of the conventions as earlier mentioned was the relegation attitudes of the government at the centre, particularly the officials of the Ministry of Labour, Employment and Productivity. Fajana (2011) argued that the objective of labour administration within the purview of the Federal Ministry of Labour, Employment and Productivity was to strengthen labour standards and practices in all sectors especially in the weak sectors in order to ensure minimum floors of protection for vulnerable groups.

But this position can only be achieved if ILS conventions ratified by Nigeria state is fully implemented and monitor for compliance by this ministry but reverse is however the 
case. This is because the ministry saddle with these responsibilities has been relegated ${ }^{5}$. Fajana (2011) was of the opinion that the implementation of ratified conventions has not always been effective owing to capacity challenges in ensuring compliance with such commitments and lack of awareness of the provision of the conventions.

However, Nigeria has always been blacklisted by ILO for flagrant violation of trade union rights and other conventions ratified. Therefore, there is need for strengthening national capacity towards the improved quality of reporting on ratified conventions and responding adequately to comments of ILO supervisory bodies in order to be among the League of Nations that preaches decent work practices.

Fajana (2011) mentioned that the Ministry of Labour, Employment and Productivity should provide relevant information to the National Assembly of the instruments adopted from international labour conferences for effective deliberation in order to determine its acceptability or not. He emphasised that this modality will enhances effective implementation of the ratified instruments.

By and large, the adoption of ratified ILO conventions by Nigeria state should be given speedy deliberation by National Assembly members in order to make it effective labour laws. Also, the labour inspectorate and other officials at the Ministry of Labour, Employment and Productivity should be properly trained and the ministry should be funded adequately in order to ensure compliance to the laws that has been consented by national assembly ${ }^{5}$. By doing so, will promotes the image of Nigeria as a member state that have ratified and excuted ILO conventions and not just a bench warmer in the meetings.

\section{Convention 87 of 1948 (Freedom of Association and Right to Organise)}

The rights of workers to associate with other persons for the purpose of forming or joining a trade union is part of the ILO convention 87 of 1948 concerning Freedom of Association and protection of the Right to Organise (Otuturu, 2009).

Article 2 of the convention provides ${ }^{8}$ as follows:

"Workers and employers, without distinction whatsoever, shall have the rights of the organisation concerned, to join organisation of their own choosing without previous authorisation".

This convention is fundamental to the existence of collective labour rights by trade unions and unionists. It was adopted on the 9th of July, 1948. Nigeria was a signatory to the convention on 17th October, 1960 (Mbah \& Ikemefuna, 2011). It provides that workers and employers have the rights to establish or join organisations of their own choice without previous authorisation ${ }^{8}$ (Article 2).
Moreso, this convention is similar to the right guaranteed by section 40 of the Federal Republic of Nigeria constitution on the right to associate freely and form trade union $^{6}$. It is also one of the rights guaranteed under the African Charter on Human and Peoples' Rights which is directly applicable in Nigeria by virtue of the African charter on Human and People' Rights (Ratification and Enforcement Act, 1990).

According to Nigeria constitution of 1999 which provides $^{6}$ as follows:

"Every person shall be entitled to assemble freely and associate with other persons and in particular he may form or belong to any political party, trade union or any other association for the protection of his interest"

But the rights to associate in line with section 40 of the constitution are not absolute because the phrase "for the protection of his interest" does not give a person an unrestrained freedom to join a trade union, which is in contrary to the ILO convention ${ }^{12}$.

Otuturu (2009) emphasised that it is not a freedom at large but rather, it is one that is certainly restrictive. Thus, a person proposing to join an association must show how that association would protect his interest. Apart from constitutional hindrances to effective implementation of ILO convention 87 of 1948. Statutory provisions also derogate from the right to form or join a trade union ${ }^{12}$.

Under the Trade unions Act 1990 as amended by the trade unions (amendment) Act 2005, membership of a trade union is generally open to all persons employed in a particular trade. Section 12 (1) of the Act provides that no person who is otherwise eligible for membership of a particular trade union shall be refused admission to membership of that union by reason only that he is of a particular community, tribe, place of origin, religion or political opinion (Otuturu,2009).

By section 12 (3) of the new Act (amended), membership of a trade union by employees shall be voluntary and no employee shall be forced to join any trade union or be victimized for refusing to join or remain a member. Also, section 11 of the Act places restrictions on certain categories of workers to form or join a trade union ${ }^{11}$.

For instance, the New Export Process Zone Act (NEPZA) Act (DN63) of 1992 makes provision for $100 \%$ repatriation of capital, profits and dividends to foreign investors. The provision provides a number of "incentives" for employers which betray the workers organising intent. These include a prohibition on strikes and lockouts, fenced walls around the zones purposely for security but which were also used to harass trade Unionists that have tried to unionise in some EPZs.

The reasons adduced by Federal Government of Nigeria for this Act is to encourage Foreign Direct Investment which according to them will yield the country GDP and promote socio-economic growth of the country. Again, government of Nigeria claimed that the Act will avert disruption in production activities at the zones and 
encourage increase in country productivity. However, the consequences of such actions are numerous which include: leading to casual labour/contract employment; subjecting of workers to long-hours of work; lack of social dialogue and promotion of unfair labour practices to mention just a few.

Strictly speaking, the NEPZA Act is in contradiction to section 40 of Nigeria 1999 constitution as well as contravene convection 87 of 1948 which provides for the right of workers to form or join trade Union. Therefore, there is need for proper review of international treaty before its domestication at the national level.

By and large, all these clauses in the Trade union Act of 2005 is inconsistent with ILO convention 87 of 1948 which provides the rights of workers to form or join trade unions is an aspect of the freedom of association for the advancement or protection of workers interest as a result calls for modification.

\section{Rights to Organise a Collective Bargaining, Convention No 98 of 1949}

The primary purpose of this convention is concerned with the application of the principle of the right to organise and to bargain collectively among the actors. This is because many individuals do not have the free background to negotiate the terms and conditions of their contract on an equal basis.

Where this takes place, collective labour interest becomes relevant and functional for the workers ${ }^{2}$. Thus, for workers to have any effective power in the employment relations, they must come together to further their demands on collective basis, workers can then stand the chance of counter balancing the powers of the employer (Deakin and Morris, 1995).

The convention seeks to protest the rights of stakeholders in industrial relations to bargain voluntarily. It has also been ratified by Nigeria on 17th October, 1960. It prohibits anti-union discrimination against Workers Article 1 (1). The right of workers to bargain freely with employers is an essential element in freedom of association.

According to the convention, collective bargaining is a voluntary process through which employers and workers discuss and negotiate their relationship, particularly in term of conditions of work. Although, this convention has been ratified by Nigeria government but it is yet to ratify convention 151 on labour relations (public service, 1978) which makes it obligatory to institute collective bargaining machinery in the public sector ${ }^{11}$.

The problem of collective bargaining in Nigeria in term of its restricted nature and the relative large number of workers outside its coverage, emanate from development in the national policy (NLC policy Document, 2010). In Nigeria, collective bargaining is regulated by many statutes among which are the Trade Union Act of 1973, the Trade Unions (Amendment) Act of 1978, the Trade Dispute Act of 1976, the Wages Boards and Industrial Council Acts of 1973 to mention a few.

The paper attention will be limited to the Wages Boards and Industrial Council Acts of 1973. This becomes pertinent as a result of frequent industrial actions caused by the failure of Nigeria government to implement most of the collective agreement borne out of collective bargaining. This Acts provides for the use of collective bargaining to determine wages in Nigeria.

Section 18 of the Act stipulates that employers and workers in an industry may establish joint industrial council for the purpose of negotiating and reaching an agreement in relations to matter of employment. Section 18 (2) further states that upon the establishment of such a council, it is agreed that constitution and functions, and any agreement by the council on any matter relating to wages or condition of employment of workers in the industry are to be registered with the minister (in-charge of labour matters) who may thereafter make an order declaring such provisions to be binding on the workers to whom they relate.

This clause of the Act contradict ILO convention 98 of 1949 and convention 151 of 1978 on the procedures for determining terms and conditions of employment. Enaiyejuni (2005) also corroborate this by saying that the Act fails to provides appropriate collective bargaining measures to national conditions which shall be taken to encourage and promote the full development and utilisation of the machinery for negotiation of terms and conditions of employment between the government and public employee organisations.

Therefore, there is need for legal review of some of these legislations, particularly those that as to do with collective bargaining and agreement in relations to ILO conventions, in order to promote strong, stable, well focused and democratically unions that will expands the scope of collective bargaining and thereby strengthen industrial democracy.

\section{Convention No 155 (Occupational Safety and Health convention of 1949)}

According to Mbah \& Ikemefuna (2011), Nigeria adopted the convention on the 22nd of June, 1981. The convention applies to all employed persons including public employees and covers all places where the workers needs to be or to go by reason of their work which are under the direct or indirect control of the employers (Article 2 \& 3).

The international labour organisation has over 30 conventions and more than 22 Recommendations on health, safety and welfare (Fajana, 1998). However, the international labour standards are the acceptable 
international minimum standards of labour practices which must be achieved and maintained by the parties in labour management.

These standards are contained in the provisions of the international labour organisation conventions and Recommendations (Eniaiyejuni, 2005). In Nigeria, relevant laws have been enacted to achieve this ILO convention Nos 155 of 1949. The Occupational Health and Safety laws are contained in the Workmen's compensation Ordinance, No 51 of 1941 as amended in 1987. Although, this has been repealed and replaced with Employee's compensation Act, 2010. The Factories Acts, No. 33 of 1955 as amended in 1987 and the National provident Fund Act No. 24 of 1961 as amended later. All these Acts and others not mentioned in this paper are responsible for occupational health and safety of workers.

The paper concern shall be limited to factories Act 1990 which is the current Nigeria legislation on health and safety of workers at workplace. The enforcement of the legislation is carried out by the factory inspectorate of the ministry of labour. According to Omokhodion (2012) this ministry produced a National policy on Safety and Health in 2006 which details the responsibilities of employers, workers, manufacturers and government agencies in the maintenance of the health and safety of workers.

The role of government is to provide the enabling legislation to set minimum standards of health and safety, and compensation for workers in case of injury or death arising from work or occupational disease ${ }^{13}$. Eniayejuni (2005) said these provisions are reflected in the workmen's compensation Act of 1942 as amended in 1987, and the factories Act of 1958. Also, capture similar clause in the present Employee's compensation Act of 2010.

Furthermore, the federal government of Nigeria through the factories inspectorate department of the federal ministry of labour is empowered to enforce standards by inspecting workplaces for hazards and ensure compliance on the part of employers ${ }^{1}$. However, compliance with ILO Conventions and Recommendations or labour standards by organisation to improve conditions of life and work must constitute the ultimate path towards good health and safety in workplaces.

But for this aspects of enforcement to ensure compliance in Nigeria, more still need to be done because of the corruption on the part of inspectorate officials and the ignorance of workers who does not understand the content of the ILO conventions and Recommendations as well as the new Employee's compensation Act of 2010.

\section{Concluding Remarks}

Nigeria as a nation fail to execute most of the ILO conventions to the logical conclusion, maybe because of the dualistic nature of the country parliamentary system or the sources of the country laws that emanated from English common laws. These reflect in the regulation of industrial relations practices in the country. As a result most statutory laws in which ILO conventions was inclusive undergone National Assembly scrutiny which takes a longer duration before enactment.

Secondly, the constitution of the Federal Republic of Nigeria lifted most of the labour matters from ILO conventions and other treaties without measuring the consequences of such conventions on the national economy. The major effects of this reflect on socio-economic relationship among the three principal actors of industural relations in the country which eventually resulted to industrial unrest in the country and affect other labour issues including trade unions density reduction.

Nevertheless, for Nigeria to compete at international arena like ILO need adequate resources both intellectual and material. This will enable them to compete favourably rather than been carpet by ILO always ${ }^{1}$. Furthermore, there is a visible relegating attitude of the government at the centre to achieve the espoused goals of labour administration. This is unconnected with corruption and lackadaisical attitude of the officials in the Ministry of Labour, Employment and Productivity to enforce compliance to most of these ratified ILO conventions.

On a final note, most of the ILO conventions are essentially only a catalyst to states to enact labour legislations. Its power of enforcement are weak, if not nonexistence therefore the supervisory bodies of ILO must work tirelessly to ensure vivid implementation of ratified conventions, failure to comply by the member states should called for stiff penalty.

In order to achieve this, the study strongly suggest a full empowerment to ILO supervisory bodies to ensure absolute enforcement among member states who has ratified the conventions rather than ILO acting as a toothless bull-dog that bark without bite. In doing so will prompt Nigeria government to discuss extensively on international treaties or laws at domestic level before designing their draconian national laws like Trade Union Acts and others that are significantly contradictory to already ratified conventions and recommendations. This can be achieved through effective sanctions that will affect the country bilateral relationship with other countries, particularly trade relationship.

\section{References}

[1] Aturu, B (2008): ILO to battle HIV/AIDS in place of work. Guardian Newspaper, Tuesday August $15^{\text {th }}$.

[2] Deakin, S \& Morris, G.S (1995): Labour Law. Butterworth's London, 594-598.

[3] Eniaiyejuni, B. O (2005): Management of Industrial Relations in Nigeria. Concept Publication, Lagos-Nigeria. 
[4] Fajana, S (1998): International Labour Standards and Occupational Health and Safety; an unpublished Seminar paper delivered at a SESCAN programme.

[5] Fajana, S (2011): Vice Chancellor bewails poor labour standards in Nigeria. Vanguard Newspaper, Wednesday August $8^{\text {th }}$.

[6] Federal Republic Of Nigeria Constitution 1999.

[7] ILO Conference Report (2003): Working out of poverty, $91^{\text {st }}$ session of the international Labour conference.

[8] ILO Convention 87 of 1948, Article 2.

[9] ILO Report (2004): A fair Globalisation- creating opportunities for all. Report of the world commission on social Dimension of Globalisation, Geneva publication.

[10] Mbah, S.E \& Ikemefuna, C.O (2011): Core conventions of the International Labour Organisation (ILO): Implications for Nigeria Labour Laws. International Journal of Business Administration, Vol 2 nos 2 p 1-8.

[11] Nigeria Labour Congress Policy Document 2010.

[12] Otuturu, G.G (2009): Freedom of Associations and Trade Unions membership in Nigeria. Nigerian Journal of Labour Laws \& Industrial Relations; Labour Laws Review vol 3 No 19 p 63-72.

[13] Omokhodion, F (2012): Occupational Health and Safety in Nigeria. Oxford Journal of Occupational Medicine, vol 59 issue 3 p 201.

[14] Somavia, J (2011): Working for social Justice is our assessment of the past and our mandate for the future. International Labour Organisation.

[15] www.ilo.org/global.com. 